\title{
Poly D, L-lactide-co-glycolic Acid (PLGA)-encapsulated CpG-oligonucleotide (ODN) on Immune Response in Cyprinus carpio against Aeromonas hydrophila
}

\author{
Govintharaj Yogeshwari ${ }^{1}$, Chandrasekar Jagruthi ${ }^{1}$, Jesu Arockiaraj ${ }^{2}$ and Ramasamy Harikrishnan ${ }^{3 *}$ \\ ${ }^{1}$ Department of Biotechnology, Bharath College of Science and Management, Thanjavur-613 005, Tamil Nadu, India \\ ${ }^{2}$ Division of Fisheries Biotechnology and Molecular Biology, Department of Biotechnology, Faculty of Science and Humanities, SRM University, Kattankulathur-603 203, \\ Chennai, Tamil Nadu, India \\ ${ }^{3}$ Department of Zoology, Pachaiyappa's College for Men, Kanchipuram-631 501, Tamil Nadu, India
}

\begin{abstract}
The effect of Poly D, L-lactide-co-glycolic acid (PLGA) encapsulated ODN 1668 nanospheres (NS) on innate and adaptive immune response in common carp, Cyprinus carpio against Aeromonas hydrophila is reported. PLGAencapsulated ODN biodegradable NS did not have a significant impact on particle size as expected of the particles was clearly positive for non-coated and coated PLGA/ODN NS. The myeloperoxidase (MPO) activity and serum haemolysin titre significantly increased in fish injected with ODN 1668 and PLGA-encapsulated ODN 1668 groups on week 4 whereas the respiratory burst (RB) activity significantly increased when administered with ODN 1668 and PLGA-encapsulated ODN 1668 (PLGA-ODN 1668) from weeks 1 to 4 . The haemoagglutinating titre was significantly enhanced in PLGA-encapsulated ODN 1668 group on week 2 while in ODN 1668 and PLGA-encapsulated ODN 1668 groups the increase manifested on week 4 . The bacterial agglutination titre significantly increased in ODN 1668 and PLGA-encapsulated ODN 1668 groups on weeks 2 and 4. The cumulative mortality in ODN 1668 and PLGAencapsulated ODN 1668 groups were 10\% each whereas it was 15\% in PLGA group. This study indicates that single administration of PLGA-encapsulated ODN 1668 nanospheres elicits better immune response than PLGA or ODN 1668 alone in C. carpio against $A$. hydrophila.
\end{abstract}

Keywords: Aeromonas hydrophila; CpG-oligonucleotide (ODN); Cyprinus carpio; Immune response; Poly D, L-lactide-co-glycolic acid (PLGA)

\section{Introduction}

In many countries in the world, intensive fish farming has become a key industry in recent decades. Cyprinus carpio is the third most frequently introduced species world-wide [1] which grow up to 120 $\mathrm{cm}$ in length and around $60 \mathrm{~kg}$ weigh $[2,3]$. Human consumption of $C$. carpio in 3000 years ago and the production exceed more than 2,50,000 tonnes during 1997 in China [4,5]. Carp constitute an ideal candidate species for intensive aquaculture in many Asian countries because of their desirable taste, rapid growth, and insatiable demand. It was a greater tolerance of low oxygen levels, pollutants, turbidity, and high salinities than most native fish [6].

With the increasing scale of aquaculture, fishes are reared at high crowded density when environmental conditions are favorable and the fish are healthy, mass mortality will occur if infectious agents are introduced into the farms, causing great financial losses. Aeromonas hydrophila is a Gram-negative rod shaped bacterium widely distributed in aquatic environments [7] which the causative agent of motile aeromonad septicemia (MAS), fin-tail rot, and epizootic ulcerative syndrome (EUS) in a wide variety of freshwater fish species [8-12] in Asian countries including China, Philippines, Thailand and India [13]. A. hydrophila is a complex of major disease problem in commercial carp farming and the farmers at present widely used to controlling of MAS using antimicrobial drugs due to unavailable of commercial vaccines such an economically important disease consideration. However, intensive fish farming antimicrobial drugs use for their treatment which associated with increased antibiotic resistance bacteria [14-17]. Although several studies have proved that various vaccine formulations may provide protection [18-22] but it was strain specific and the conventional vaccines are often considered ineffective due to lack of appropriate adjuvant and/or suitable vaccine carrier.

In contrast to other carriers, nano and microparticles are more stable and could elicit both humoral as well as cellular immunity in mammals [23]. By being efficient antigen delivery vehicles they have the potential advantages of reducing the number of injections, enhancing the immune response, and minimize the total antigen dose needed to achieve protection [24-27]. Among the two classes of carriers the Poly ${ }_{\mathrm{D}}$, L-lactide-co-glycolic acid (PLGA) nanoparticles have been widely used for controlled delivery of peptides, vaccine, native and synthetic proteins [29], and nucleic acids [30]; indeed because of their excellent tissue compatibility, biodegradability, non-toxic nature application of nanoparticles have been approved by the Food and Drug Administration for safe use in human and animals.

In fish the intra-peritoneal administration of PLGA nanoparticles is reported to stimulate certain non-specific immune response and pro-inflammatory cytokine production [31]. With reference to biodegradability, the use of PLGA nanoparticles as a vaccine carrier has been investigated through oral administration in fish such as rainbow trout $[32,33]$.

*Corresponding author: HariKrishna R, Department of Zoology, Pachaiyappa's College for Men, Kanchipuram - 631 501, Tamil Nadu, India, Tel: +91 4362 227937; E-mail: rhari123@yahoo.com

Received January 14, 2015; Accepted February 14, 2015; Published March 15 2015

Citation: Yogeshwari G, Jagruthi C, Arockiaraj J, Harikrishnan R (2015) Poly D L-lactide-co-glycolic Acid (PLGA)-encapsulated CpG-oligonucleotide (ODN) on Immune Response in Cyprinus carpio against Aeromonas hydrophila. J Aquac Res Development 6: 327. doi:10.4172/2155-9546.1000327

Copyright: $\odot 2015$ Yogeshwari G, et al. This is an open-access article distributed under the terms of the Creative Commons Attribution License, which permits unrestricted use, distribution, and reproduction in any medium, provided the original author and source are credited. 
Citation: Yogeshwari G, Jagruthi C, Arockiaraj J, Harikrishnan R (2015) Poly D, L-lactide-co-glycolic Acid (PLGA)-encapsulated CpG-oligonucleotide (ODN) on Immune Response in Cyprinus carpio against Aeromonas hydrophila. J Aquac Res Development 6: 327. doi:10.4172/21559546.1000327

The innate immune system can recognize and differentiate the unmethylated oligonucleotides containing CGdinucleotides-CpG motifs (CpG ODNs) from the vertebrate's methylated DNA with the help of pattern recognition receptors (PRRs) which trigger immune response against the perceived threat of bacterial infection [34]. Recently CpG ODN motifs of bacterial DNA are recognized as a new class of adjuvants [35]; since they can induce a strong humoral and cellular immune response with a bias towards a T-helper type 1 (Th1) response [36]. CpG ODN treatment stimulated leucocyte immune activities in teleost fishes $[37,38]$. However, there is no report of PLGA encapsulated within CpG ODN in fish through intra-peritoneal administration in fishes. Hence the present study was undertaken to evaluate the efficacy of PLGA nanoparticles encapsulated CpG ODN nanospheres on innate and adaptive immune responses in $C$. carpio against $A$. hydrophila infection.

\section{Materials and Methods}

\section{Chemicals}

ODNs sequence of ODN 1668 (5'-TCCATGACGTTCCTGATGCT-3') were synthesized by Bioneer Corporation, Korea and the nucleotides were underlined as indicate phosphorothioate linkage. PLGA 50:50 co-polymer (inherent viscosity $0.17 \mathrm{dl} / \mathrm{g}$ in hexafluroisopropanol) was purchased from Birmingham Polymer Inc. (Birmingham, AL, USA). Polyvinyl alcohol (PVA) (87-89\% hydrolyzed, 31000-50000 g/mol) was purchased from Merck (Darmschtadt, Germany). The organic solvents used were of HPLC grade.

\section{Preparation of PLGA-encapsulated CpG ODN nanospheres}

PLGA microparticle encapsulated CpG ODN 1668 nanospheres (NS) was formulated using a double emulsion-solvent evaporation technique [39] with small modification. Briefly, 50 ug of ODN 1668 dissolved in $500 \mu \mathrm{l}$ of phosphate buffered saline (PBS, pH 7.2) was emulsified with $150 \mathrm{mg}$ of PLGA in chloroform solution $(5 \% \mathrm{w} / \mathrm{v})$ followed by vortexing for $3 \mathrm{~min}$ to get a primary emulsion. The primary emulsion was further emulsified in an aqueous PVA solution $(15 \mathrm{ml}, 5 \% \mathrm{w} / \mathrm{v})$ to form an oil-in-water emulsion. For preparation of nanospheres, the emulsion was homogenized for $3 \mathrm{~min}$ and stirred overnight at room temperature to allow the evaporation of organic solvent. Nanospheres were recovered by normal centrifugation at 5000 $\mathrm{xg}$ for $20 \mathrm{~min}$ (SIGMA 3K30, Germany). The process of centrifugation was repeated three times to remove excess PVA and un-encapsulated CpG ODN. The recovered nanospheres suspensions were lyophilized for two days $\left(-80^{\circ} \mathrm{C}\right.$ and $<10 \mathrm{~mm}$ mercury pressure (LYPHLOCK, Labconco, Kansas City, MO) to get lyophilized powder for further use. PLGA microparticle encapsulated CpG ODN nanospheres was performed by scan electron micrograph as shown in Figure 1.

\section{NS characterization}

NS morphology and particle size measurement: The NS morphology was determined by scanning electron microscopy (SEM). The size and size distribution of the NS were analyzed by a laser lightscattering method (Mastersizer, Malvern Instruments, UK). Particle size distributions were calculated in the volume-weight mode and characterized as mean diameter, and were used to determine the span of the distribution.

Zeta $(\zeta)$ potential analysis: The zeta $(\zeta)$-potential was determined in a Zeta Plus Potential Analyzer (Brookhaven Instruments Corporation, New York, USA).

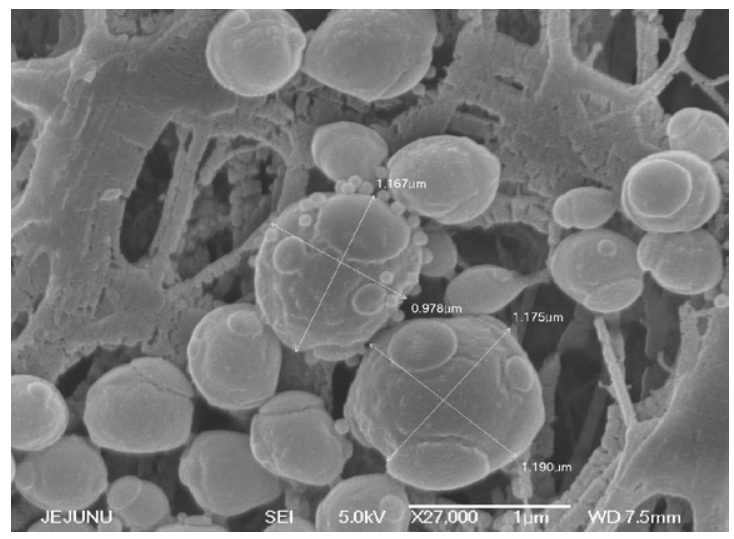

Figure 1: PLGA nanoparticle-encapsulated CpG ODN nanospheres performed by scan electron micrograph.

Encapsulation efficiency: Twenty milligrams of NS were dissolved in $0.1 \mathrm{M}$ acetic acid for $18 \mathrm{~h}$, and the sample was then centrifuged for 20 $\min$ at $20,000 \times \mathrm{g}$. The protein was measured by a spectrophotometric assay, with a Quanti Pro BCA assay kit (Sigma Aldrich).

Coupling efficiency: The amount of protein in the NS was quantified with a Quanti Pro BCA assay. The amount of unbound ODN recovered by centrifuging and washing the NS was subtracted from the initial amount of protein. The fluorescence was also measured with Fluorostar Optima equipment (BMG Labtech, Biogen, Madrid, Spain) at $485 \mathrm{~nm}$ fluorescence excitation and $520 \mathrm{~nm}$ for emission and wavelength, respectively.

\section{In vivo experiment}

Aeromonas hydrophila: A. hydrophila was associated from bacterial haemorrhagic septicemia of goldfish (C. auratus) in India and maintained in the laboratory [40]. It was cultured in extract-peptone medium broth at $27^{\circ} \mathrm{C}$ overnight, then sub-cultured into new medium for $12 \mathrm{~h}$. Then the bacteria were washed with PBS and re-suspended in PBS prior to use. The desired number of bacteria was adjusted by measuring the optical density at $600 \mathrm{~nm}$, corresponding to $1.3 \times 10^{8}$ cells $\mathrm{ml}^{-1}$.

Administration protocol: Healthy common carp, Cyprinus carpio, average weight ranging from 29 to $35 \mathrm{~g}$ was purchased from commercial fish farm and acclimatized with $500 \mathrm{~L}$ aerated cement tanks for 2 weeks in the wet laboratory. One-third of the water was exchanged daily and the water temperature, $\mathrm{pH}$, dissolved oxygen, and salinity were measured at $28.8 \pm 1.5^{\circ} \mathrm{C}, 7.6 \pm 0.7,5.61 \pm 0.64 \mathrm{mg}$ $\mathrm{L}^{-1}$, and $31.1 \pm 1.1 \%$, respectively during the experimental period. For the immunological assay, the fish were divided into three groups of 25 each in triplicate set and injected separately each with $100 \mu$ of PLGA, CpG ODN 1668, and PLGA-encapsulated ODN 1668 (PLGA+ODN 1668) nanospheres. After 3 week post-injection all groups were injected intra-peritoneally (i.p.) with $100 \mu \mathrm{l}$ PBS containing A. hydrophila at $1.3 \times 10^{8}$ cells $\mathrm{ml}^{-1}$. Another two groups of 25 fish each were maintained separately for controls and injected with $100 \mu$ of PBS (C) or bacteria (I). Six fish were randomly collected in each treated groups including the control groups and $0.5 \mathrm{ml}$ of blood was collected from vein at weeks 1,2, and 4 post-infection after anaesthetised with MS-222 ( $\mathrm{NaHCO}_{3}$ and tricaine methanesulphonate; Sigma Chemicals) 1:4000 in dechlorinated water for immunological assay. Only 20 fish in each group were used separately for the challenge study and record the 
Citation: Yogeshwari G, Jagruthi C, Arockiaraj J, Harikrishnan R (2015) Poly D, L-lactide-co-glycolic Acid (PLGA)-encapsulated CpG-oligonucleotide (ODN) on Immune Response in Cyprinus carpio against Aeromonas hydrophila. J Aquac Res Development 6: 327. doi:10.4172/21559546.1000327

Page 3 of 7

cumulative mortality and relative percent survival (RPS) over a period of 30 days [41].

Immunological assays: The myeloperoxidase activity was determined with $15 \mu \mathrm{l}$ of serum and diluted in $135 \mu \mathrm{l}$ of Hank's balanced salt solution (HBSS; $\mathrm{Ca}^{2+}, \mathrm{Mg}^{2+}$ free). After this $50 \mu \mathrm{l}$ of 20

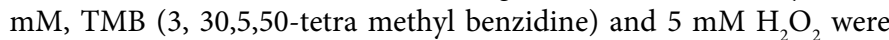
added. The reaction was stopped after 2 min by adding $50 \mu \mathrm{l}$ of $4 \mathrm{M}$ sulphuric acid and the optical density (O.D.) was read at $450 \mathrm{~nm}$ [42] using UV-VIS spectrophotometer (Thermo Spectronic, UK). The respiratory burst activity was measured by the reduction of nitro blue tetrazolium (NBT) by intracellular superoxide radicals [43]. For bacterial agglutination test, two-fold serial dilutions of $25 \mu \mathrm{l}$ fish serum was made and an equal volume of PBS was added in each well; then addition of $25 \mu \mathrm{l}$ of formalin killed A. hydrophila $\left(1.3 \times 10^{8}\right.$ cells $\mathrm{ml}^{-1}$ suspension) in ' $U$ '-shaped microtitre plates according to Behera et al. [33]. The haemagglutination activity of serum samples was carried out using a standard methods of Blazer and Wolke [44] and Behera et al. [33] using ' $U$ '-shaped microtitre plates by two-fold serial dilution. The haemolytic titre of serum was determined as described previously [44] and Behera et al. [33] in haemoagglutination titre by using fresh sera from all the groups.

\section{Statistical analysis}

The statistical analysis system (SAS) software (version 6.12) was used to analyse each data. One-way analysis of variance followed by Duncan's multiple range test were done to compare the variations in various immune parameters at $\mathrm{p}<0.05$ significance level difference between the injected groups. The mean standard error $( \pm$ S.E) of assayed parameters was calculated for each group of fish.

\section{Results}

\section{Particle size, $\zeta$-potential, morphology, coupling efficiency of PLGA/ODN NS}

The best formulation for in vivo studies was selected on the basis of the coupling efficiency results. To assess the particle size and the $\zeta$-potential after ODN coupling, both parameters were measured before and after coating. The particle size and $\zeta$-potential of the PLGA/ ODN NS are presented in Table 1. The present study there were no significant differences between the mean size of NS of the formulations, and incorporation of the ODN did not lead to an increase in the mean diameter of the NS. Furthermore, ODN encapsulation did not have a significant impact on particle size. As expected, the $\zeta$-potential of particles was clearly positive for non-coated and coated PLGA/ODN nanospheres. The $\zeta$-potential varied when the NS were coated with ODN, confirming the surface modification of PLGA/ODN NS (Table 1) due to the polycationic charge of PLGA and ODN. The surface and shape of NS were also examined by SEM as shown in Figure 1. Topology and size of the microparticle as observed by SEM analysis confirmed the smooth and spherical nature of ODN-loaded PLGA NA.

\section{Mortality}

The least cumulative mortality of $10 \%$ (RPS: $88.9 \%)$ was observed

\begin{tabular}{|l|c|c|c|}
\hline & Size $(\boldsymbol{\mu m})$ & $\begin{array}{c}\text { Zeta }(\zeta) \text { potential of } \\
\text { PLGA-ODN NS }\end{array}$ & $\begin{array}{c}\text { Coupling efficiency } \\
(\boldsymbol{\mu g} / \mathbf{m g} \text { of } \mathbf{N S})\end{array}$ \\
\hline Without PLGA \& ODN & 1.12 & $+32.12 \pm 0.18$ & - \\
\hline PLGA & 1.32 & $+33.27 \pm 0.23$ & $38.3 \pm 0.5$ \\
\hline PLGA containing ODN & 1.44 & $+34.34 \pm 0.36$ & $40.8 \pm 0.7$ \\
\hline
\end{tabular}

Table 1: Variation of size, zeta potential, and coupling efficiency.

\begin{tabular}{|c|c|c|c|c|c|}
\hline Groups & Tank & $\begin{array}{l}\text { Cumulative } \\
\text { mortality (\%) }\end{array}$ & $\begin{array}{c}\text { Mean } \\
\text { cumulative } \\
\text { mortality (\%) }\end{array}$ & RPS $^{b}$ & $\begin{array}{c}\text { Statistical }(\%) \\
\text { significance } \\
\left(X^{2} \text { test }\right)^{c}\end{array}$ \\
\hline \multirow[t]{3}{*}{ Control } & A & $20 / 20=100$ & 100 & & \\
\hline & B & $20 / 20=100$ & & & \\
\hline & C & $20 / 20=100$ & & & \\
\hline \multirow[t]{3}{*}{ Infected } & A & $16 / 20=80$ & 90 & & \\
\hline & $\mathrm{B}$ & $18 / 20=90$ & & & \\
\hline & C & $20 / 20=100$ & & & \\
\hline \multirow[t]{3}{*}{ PLGA } & $A$ & $3 / 20=15$ & 15 & 83.3 & $P<0.05$ \\
\hline & $B$ & $2 / 20=10$ & & & \\
\hline & C & $4 / 40=20$ & & & \\
\hline \multirow[t]{3}{*}{ ODN } & $A$ & $1 / 20=5$ & 10 & 88.9 & $P<0.05$ \\
\hline & B & $3 / 20=15$ & & & \\
\hline & C & $2 / 20=20$ & & & \\
\hline \multirow[t]{3}{*}{ PLGA+ODN } & A & $1 / 20=5$ & 10 & 88.9 & $P<0.05$ \\
\hline & B & $4 / 20=20$ & & & \\
\hline & C & $1 / 20=5$ & & & \\
\hline
\end{tabular}

${ }^{a}$ Cumulative mortality was calculated control and immunized groups.

${ }^{\mathrm{b}} \mathrm{RPS}=\{1-(\%$ mortality of immunized group $/ \%$ mortality of non-immunized group) $\} \times 100$.

'Statistical significance is based on a comparison to results for the non-immunized group.

Table 2: Cumulative mortality ${ }^{a}$ and relative percent survival of kelp grouper after immunization with PLGA and ODN 1668.

\section{$\square \mathrm{C} \square \mathrm{I} \square \mathrm{PLGA} \square$ ODN $1668 \square$ PLGA+ODN 1668}

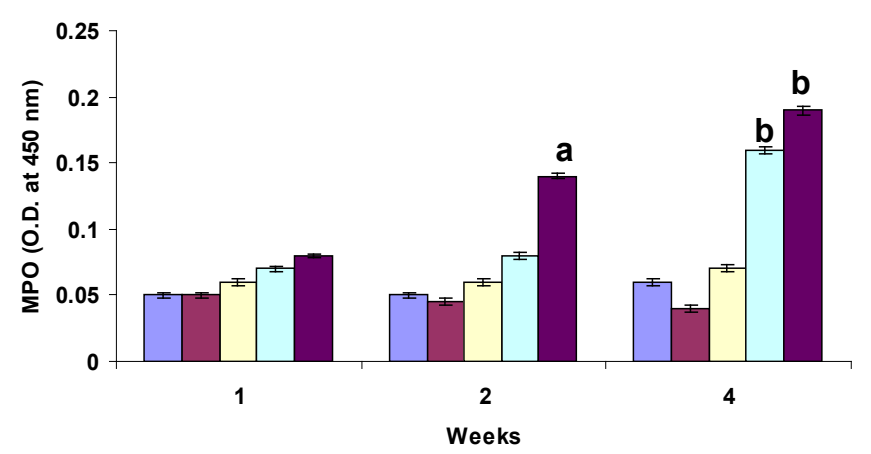

Figure 2: Myeloperoxidase (MPO) activity of C. carpio $(n=6)$ control (C), infected (I), and injected with PLGA, ODN 1668, and PLGA-encapsulated ODN 1668 against $A$. hydrophila. Data (mean $\pm \mathrm{SE}$; $\left.{ }^{*} \mathrm{P}<0.05\right)$ difference from the control is indicated with different letters.

in fish injected with ODN 1668 and PLGA-encapsulated ODN 1668 nanospheres during a period of 30 days and in PLGA group the mortality was $15 \%$ (RPS: $83.3 \%$ ). In infected and non-injected group the cumulative mortality was $90 \%$ while no mortality was observed in control group (Table 2).

\section{Myeloperoxidase (MPO) activity}

The myeloperoxidase (MPO) activity did not significantly vary in any experimental group on first week when compared to the control against pathogen. Fish injected with PLGA-encapsulated ODN 1668 nanospheres had significantly increased MPO activity on week 2 which was not observed in other groups. On week 4, fish injected with ODN 1668 and PLGA-encapsulated ODN 1668 nanospheres had significantly increased MPO activity against pathogen; however, the activity did not significantly increase in PLGA group on week 4 (Figure 2). 
Citation: Yogeshwari G, Jagruthi C, Arockiaraj J, Harikrishnan R (2015) Poly D, L-lactide-co-glycolic Acid (PLGA)-encapsulated CpG-oligonucleotide (ODN) on Immune Response in Cyprinus carpio against Aeromonas hydrophila. J Aquac Res Development 6: 327. doi:10.4172/21559546.1000327

\section{Respiratory burst (RB) activity}

The respiratory burst (RB) activity was not significantly enhanced PLGA administered group from weeks 1 to 4; however with ODN 1668 and PLGA-encapsulated ODN 1668 nanospheres it significantly enhanced from weeks 1 to 4 (Figure 3).

\section{Serum haemoagglutinating titre}

The serum haemoagglutinating titre did not significantly increase in any experimental group on first week when compared to the control. The titre significantly increased more with PLGA-encapsulated ODN 1668 group on week 2 than with PLGA or ODN 1668 alone. On the other hand, it significantly increased in ODN 1668 alone or PLGAencapsulated ODN 1668 nanospheres on week 4 against pathogen (Figure 4).

\section{Serum haemolysin titre}

In all the groups, the serum haemolysin titre did not enhance significantly on first week when compared to the control against pathogen. On weeks 2 and 4 , it was significantly enhanced in fish injected with ODN 1668 and PLGA-encapsulated ODN 1668 nanospheres but not in PLGA alone (Figure 5).

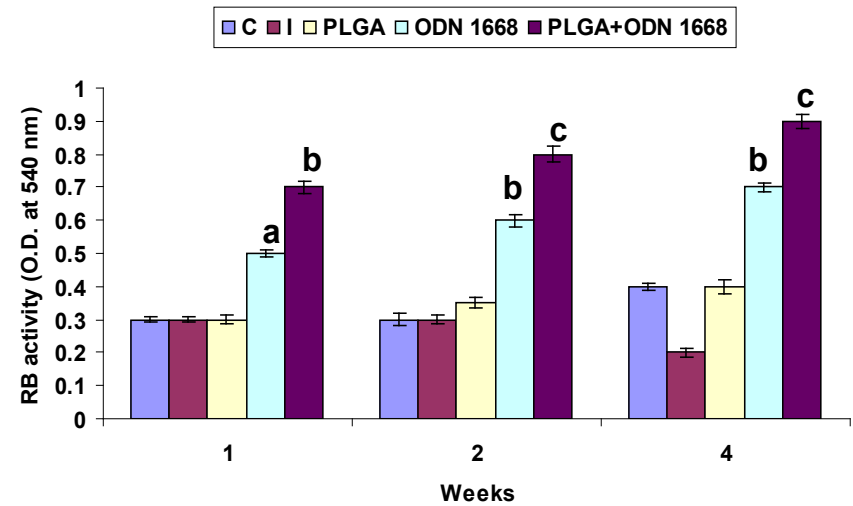

Figure 3: Respiratory burst (RB) activity of $C$. carpio $(n=6)$ control $(C)$, infected (I), and injected with PLGA, ODN 1668, and PLGA-encapsulated ODN 1668 against $A$. hydrophila. Data (mean $\pm \mathrm{SE} ;{ }^{*} \mathrm{P}<0.05$ ) difference from the control is indicated with different letters.

$\square \mathrm{C} \square \mathrm{I} \square \mathrm{PLGA} \square$ ODN $1668 \square$ PLGA+ODN 1668

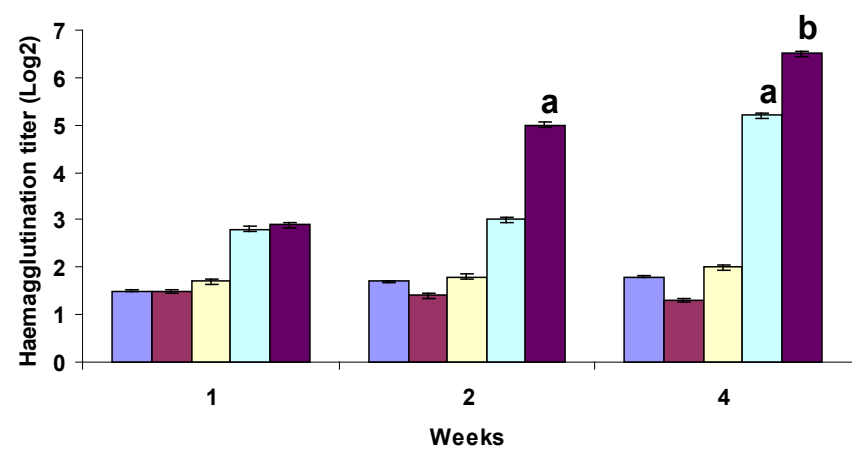

Figure 4: Serum haemoagglutinating activity (titre) of $C$. carpio $(n=6)$ control (C), infected (I), and injected with PLGA, ODN 1668, and PLGA-encapsulated ODN 1668 against $A$. hydrophila. Data (mean $\pm \mathrm{SE}$; ${ }^{*} \mathrm{P}<0.05$ ) difference from the control is indicated with different letters.

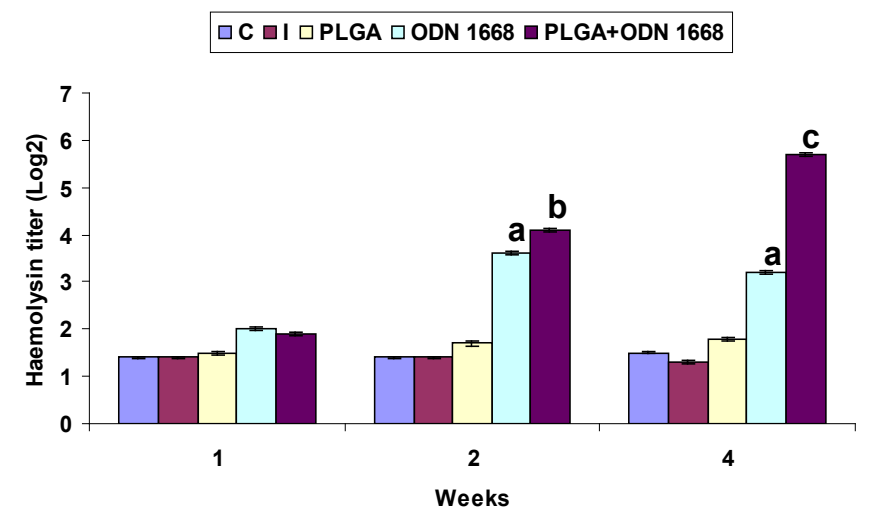

Figure 5: Serum haemolysin activity (titre) of $C$. carpio $(n=6)$ control (C), infected (I), and injected with PLGA, ODN 1668, and PLGA-encapsulated ODN 1668 against $A$. hydrophila. Data (mean $\pm \mathrm{SE}$; ${ }^{*} \mathrm{P}<0.05$ ) difference from the control is indicated with different letters.

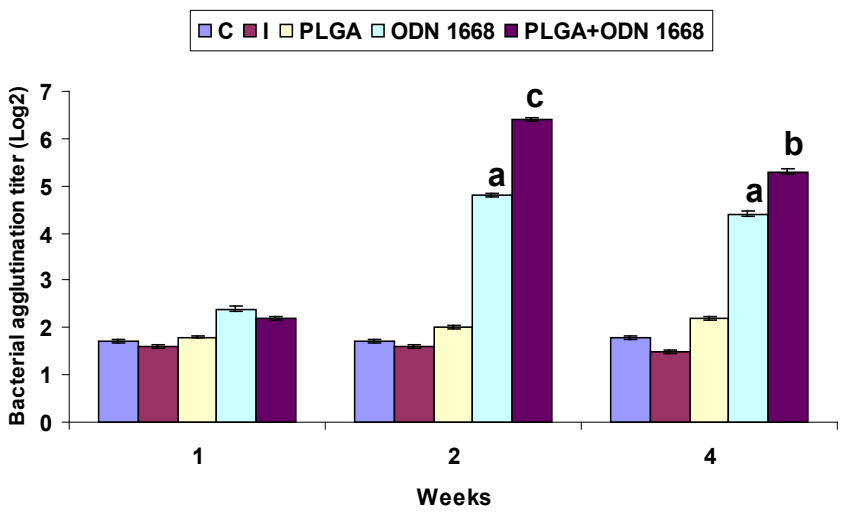

Figure 6: Bacterial agglutination activity (titre) of $C$. carpio $(n=6)$ control $(C)$, infected (I), and injected with PLGA, ODN 1668, and PLGA-encapsulated ODN 1668 against $A$. hydrophila. Data (mean $\pm \mathrm{SE}$; ${ }^{*} \mathrm{P}<0.05$ ) difference from the control is indicated with different letters.

\section{Bacterial agglutination titre}

The bacterial agglutination titre did not significantly increase in any group on first week. On the other hand, the bacterial agglutination titre significantly increased in fish injected with ODN 1668 alone or PLGA-encapsulated ODN 1668 nanospheres against pathogen on weeks 2 and 4 . However, there was no significant difference in bacterial agglutination titre in fish injected with PLGA alone (Figure 6).

\section{Discussion}

CpG ODN could impart particulate nature to soluble antigens and increase their interaction with APCs and macrophages. It can deliver peptide antigens to APCs [45] and generate Th1 type immune response, even against poor immunogens [46]. They have been used to co-encapsulate the antigen(s) which serve as an adjuvant to deliver the antigen and stimulatory adjuvant to the same APC; it induces stronger immune response when compared to the free antigens and adjuvants. CpG ODN motifs act as an immune adjuvant inducing strong humoral and cellular immune responses with a bias towards a Th1 response $[47,48]$.

NS consisting of biodegradable polymer particles represent a promising antigen or protein delivery system and slow release 
Citation: Yogeshwari G, Jagruthi C, Arockiaraj J, Harikrishnan R (2015) Poly D, L-lactide-co-glycolic Acid (PLGA)-encapsulated CpG-oligonucleotide (ODN) on Immune Response in Cyprinus carpio against Aeromonas hydrophila. J Aquac Res Development 6: 327. doi:10.4172/21559546.1000327

Page 5 of 7

for immunotherapy. It was prove a number of advantages over conventional delivery systems. For example, the microencapsulation has been acts in an adjuvant capacity via increased uptake by APCs [49] and the diameter of the NS produced in this work (1 to $10 \mu \mathrm{m})$ was adequate to allow their uptake by professional APC [50]. In the present study, two types of NS formulations were tested: (i) PLGA and PLGA-encapsulated ODN biodegradable NS. Our main objective was to determine the immunogenicity of NS with ODN preparations, using fish as experimental model. In the present study there were no significant differences between the mean size of NS of the formulations, and incorporation of the ODN did not lead to an increase in the mean diameter of the NS. In addition PLGA-encapsulated ODN biodegradable NS did not have a significant impact on particle size as expected of the particles was clearly positive for non-coated and coated PLGA/ODN nanospheres.

In the present study show that PLGA-encapsulated ODN 1668 resulted in a significant increase in the MPO activity on week 2 whereas with ODN 1668 alone and PLGA-encapsulated ODN 1668 groups the activity increased only on week 4 . It is well known that PLGA has been reported to act as a very useful antigen delivery system in mammal since it provides long lasting immunity [51]. The humoral immune response of mice to PLGA-MS, on receiving a single injection of MS containing OVA and $\mathrm{CpG}$ oligonucleotides (MS-OVA-CpG) indicates a robust IgG1 and IgG2a response suggesting a balanced Th1/Th2 response. The enhanced response after heterologous as opposed to homologous boosting with MS-OVA/CpG, the potential of PLGA-MS- and IFAbased vaccination induced in vivo proliferation of OVA-specific CD8 ${ }^{+}$ and $\mathrm{CD} 4^{+} \mathrm{T}$ cells derived from OT-1 and OT-2 mice at several time points after vaccination has been reported [52]. In the present study, the MPO activity did not significantly increase in any experimental group on first week. The results are in agreement when PLGA-MS containing either tPrP or CpG-ODN alone or in combination which failed to induce detectable immune response in treating cancer.

With respect to the immune response of the formulations, the NS containing NS covalently coupled to the surface induced respiratory burst activity was more significantly enhanced in ODN 1668 alone and PLGA-encapsulated ODN 1668 nanospheres from weeks 1 to 4 than with PLGA in this study. The haemoagglutinating titre was significantly enhanced with PLGA-encapsulated ODN 1668 on week 2 while with ODN 1668 and PLGA-encapsulated ODN 1668 groups the increase manifested on week 4 . However, the formulations of NS with encapsulated ODN induced almost no serum haemoagglutinating titre in any group on first week. Comparable results have also been reported by the use of PLGA alone in mammal as well as in fish like rainbow trout [53]. Similarly Japanese flounder after immunization with PLGAencapsulated DNA vaccine had increased immune response such as Superoxide dismutase assay (SOD) and respiratory burst activities against lymphocystis disease virus (LCDV) [54]. In grass carp after administration with ODN-1826 and -2006, ODN-1670, and ODN-D could activate macrophages, increasing the levels of superoxide anion [55]. The efficacy of PLGA particles as antigen carrier has been evaluated indicating high potencies in activating the adaptive immune response in mammals [56]. Stimulation of the immune system has been investigated after intramuscular and intradermal administration of free or lipid complexed CpG ODN alone or in combination with peptide, protein or DNA vaccination $[57,58]$. A recent study indicates that CpG-ODN 1668 might activate an alternative pathway of complement in olive flounder, which is an important innate immune factor in conferring resistance against $P$. dicentrarchi infection [59]. In rainbow trout the serum lysozyme activity was enhanced when injected with
$10 \mathrm{mg}$ and $3.16 \mathrm{mg}$ of CpG ODN 2133 [60]. In common carp treated with $\mathrm{CpG}$ ODN B and $\mathrm{C}$ activated macrophages, increasing the level of production of superoxide anion and phagocytic activity [61].

The haemoagglutinating titre was significantly enhanced in PLGA-encapsulated ODN 1668 on week 2 and ODN 1668 and PLGA-encapsulated ODN 1668 nanospheres on week 4 but not in any other group on first week. The serum haemolysin titre was significantly enhanced in ODN 1668 and PLGA-encapsulated ODN 1668 groups on week 2 and 4 but not in PLGA. Similar results were also found when PLGA was used as carrier for peptide vaccine in mammals [62]. Moreover, the superiority of PLGA microspheres over alum adjuvant in eliciting high antibody and immune response responses was seen in mice through subcutaneous administration [63]. The present results are in agreement with that of rainbow trout injected with 10, 1.0, and $0.1 \mathrm{mg}$ of CpG-ODN 2133 which induced a higher antibody titre [64]. Atlantic salmon after treatment with PLGA incorporated human gamma globulin or antigen [65] and Japanese flounder after treatment with PLGA-encapsulated plasmid vaccine against LCDV [66] also produced similar results. According to O'Hagan et al. [67], the antibody levels remained high even one year after subcutaneous injection in mice which indicate that the injectable PLGA microparticles control the release of antigen over a period of several weeks. CpG motifs co-encapsulated into PLGA 502 induced higher antibody titres and increased production of IgG2a antibodies that OVA microencapsulated alone, being more effective that both coadministered freely in solution. On the contrary, co-delivery of $\mathrm{CpG}$ and OVA in PLGA 756 microparticles decreased IgG2a improved antibody response in mice immunized with OVA CpG PLGA 502 in comparison with CpG simply co-administered with the antigen.

The bacterial agglutination titre significantly increased in fish injected with ODN 1668 and PLGA-encapsulated ODN 1668 nanospheres on weeks 2 and 4 . In the present study administration with PLGA-encapsulated ODN 1668 nanospheres showed encouraging results without any adverse effects on fish health. Correspondingly the cumulative mortality was 10\% in ODN 1668 and PLGA-encapsulated ODN 1668 nanospheres while it was 15\% in PLGA indicating their potential role in fish disease management in aquaculture. Similarly, olive flounder injected with a high dose of CpG ODN 1668 or GpCODN 1720 suffered a high mortality of 70\%. In Nile tilapia immunized with PBS, PBS+ODN 21 and PBS+ODN 2007 the cumulative mortality ranged from 70 to $60 \%$; on the other hand administration of QCDCR, and QCDCR+ODN 18S, inflicted a cumulative mortality was $80 \%$ each; but with QCDCR+ODN 2007 the observed mortality was reduced to $20 \%$ indicating the species specific result as a function of vaccine and the dosage. In rainbow trout the CpG-ODNs significantly enhance the survival against bacteria. Olive flounder administered with CpGODN 1668 showed a significantly higher survival against $M$. avidus infection. Later, Jørgensen et al. [67] reported in vivo enhancement of resistance against IPNV challenge in Atlantic salmon by i.p. injection of CpG-ODN 1681 (B-class ODN). Biochemical properties, as well as other parameters, such as release and stability, must be determined for each preparation so that each new batch of PLGA-encapsulated NS is characterized. The present study indicates that single injection with PLGA-encapsulated ODN 1668 nanospheres elicits better immune response than those of PLGA or ODN 1668 alone in C. carpio against A. hydrophila. This was agreement with PLGA microparticles as a vaccine carrier can reduce the number of administrations and induce both innate and adaptive immunity in rohu. Although the mechanisms responsible for the protective effects of this NS in fish are not well understood, the fact that the components used in its formulation 
Citation: Yogeshwari G, Jagruthi C, Arockiaraj J, Harikrishnan R (2015) Poly D, L-lactide-co-glycolic Acid (PLGA)-encapsulated CpG-oligonucleotide (ODN) on Immune Response in Cyprinus carpio against Aeromonas hydrophila. J Aquac Res Development 6: 327. doi:10.4172/21559546.1000327

Page 6 of 7

are already approved for clinical use favours use of this ODN in the development of a more effective and safer immunostimulant against disease. Further detailed molecular and immunological studies are necessary to confirm the efficacy in other fishes.

\section{References}

1. Saikia SK, Das DN (2009) Feeding ecology of common carp (Cyprinus carpio L.) in a rice-fish culture system of the Apatani plateau (Arunachal Pradesh, India). Aquat Eco 43: 559-568.

2. Allen GR (1989) Freshwater Fishes of Australia. T.F.H Publications, Sydney

3. Pinto AC, Guarieiro LLN, Rezende MJC, Ribeiro NM, Torres EA, et al. (2005) Biodiesel: an overview. J Braz Chem Soc 16: 1313-1330.

4. Li HW, Moyle PB (1993) Domestication of the carp Cyprinus carpio L. Inland fisheries management in North America.

5. Koehn J, Brumley A, Gehrke P (2000) Managing the Impacts of Carp.

6. http://www.dpi.nsw.gov.au/aboutus/resources/corporate-publications.

7. González J, Auró de Ocampo A, Anislao V (2002) Evaluation of the common carp (Cyprinus carpio, var. communis) growth fed when ensiled pig feces. Veterinaria México 33: 109-118.

8. Austin B, Austin DA (1993) Bacterial fish pathogens: disease in farmed and wild fish. Ellis Horwood, Chichester, United Kingdom.

9. Austin B, Adams C (1996) Fish pathogens.

10. Michael C, Kerouault B, Martin C (2003) Chloramphenicol and florfenico susceptibility of fish-pathogenic bacteria isolated in France: comparison of minimum inhibitory concentration, using recommended provisory standards for fish bacteria. J Appl Microbiol 95: 1008-1015.

11. Angka SL, Lam TJ, Sin YM (1995) Some virulence characteristics of Aeromonas hydrophila in walking catfish (Clarias gariepinus). Aquaculture 130: 103-112.

12. Austin B, Austin DA (1993) Bacterial fish pathogens. Diseases of farmed and wild fish. Springer Praxis, Chichester, England.

13. Chen HQ, Lu CP (1991) Study on pathogen of bacterial hemorrhagic septicemia of rice eel. Chinese J Zoonoses 7: 21-23.

14. Ko CW, Yu KW, Liu CY, Huang CT, Leu SH, et al. (1996) Increasing antibiotic resistance in clinical isolates of Aeromonas strains in Taiwan. Antimicrob Agents Chemother 40: 1260-1262.

15. Mirand CD, Zemelman R (2002) Antimicrobial multiresistance in bacteria isolated from freshwater Chilean salmon farms. Sci Total Environ 293: 207-218.

16. Schwarz S, Noble WC (1999) Aspects of bacterial resistance to antimicrobials used in veterinary dermatological practice. Vet Dermatol 10: 163-176.

17. Vivekanandhan G, Savithamani K, Hatha AAM, Lakshmanaperumalsamy $P$ (2002) Antibiotic resistance of Aeromonas hydrophila isolated from marketed fish and prawn of South India. Int J Food Microbiol 76: 165-168.

18. Chandran MR, Aruna BW, Logambal SM, Dinakaran MR (2002) Immunisation of Indian major carps against Aeromonas hydrophila by intraperitoneal injection. Fish Shellfish Immunol 13: 1-9.

19. Lamers CHJ, Van Muiswinkel WB (1986) Natural and acquired agglutinins to Aeromonas hydrophila in carp (Cyprinus carpio). Can J Fish Aquat Sci 43: 619-624.

20. Loghothetis PN, Austin B (1994) Immune response of rainbow trout (Oncorhynchus mykiss, Walbaum) to Aeromonas hydrophila. Fish Shellfish Immunol 4: 239-254.

21. Newman SG (1993) Bacterial vaccines for fish. Annu Rev Fish Dis 3: 145-185

22. Rahman MH, Kawai K (2000) Outer membrane proteins of Aeromonas hydrophila induce protective immunity in goldfish. Fish Shellfish Immunol 10: 379-382.

23. Men Y, Thomasin C, Merkle HP, Gander B, Corradin G (1995) A single administration of tetanus toxoid in biodegradable microspheres elicits $T$ cell and antibody response similar or superior to those obtained with aluminum hydroxide. Vaccine 7: 683-689.

24. Eldridge JH, Staas JK, Meulbroek JA, McGhee JR, Tice TR, et al. (1991) Biodegradable microspheres as a vaccine delivery system. Mol Immunol 28: 287-294.
25. Eldridge JH, Staas JK, Meulbroek JA, Tice TR, Gilley RM (1991) Biodegradable and biocompatible poly(d,I-lactide-co-glycolide) microspheres as an adjuvant for staphylococcal enterotoxin-B toxoid which enhances the level of toxinneutralizing antibodies. Infect Immun 59: 2978-2986.

26. O'Hagan DT, Jeffery H, Roberts MJJ, McGee JP, Davis SS (1991) Controlled release microparticles for vaccine development. Vaccine 9: 768-771.

27. Partidos CD, Vohra P, Jones D, Farrar G, Steward MW (1997) CTL responses induced by a single immunization with peptide encapsulated in biodegradable microparticles. J Immunol Methods 206: 143-151.

28. Kirby DJ, Rosenkrands T, Agger EM, Andersen P, Coombes AG, et al. (2008) PLGA microspheres for the delivery of a novel subunit TB vaccine. J Drug Targ 16: 282-293.

29. O'Donnell GB, Reilly P, Davidson GB, Ellis AE (1996) The uptake of human gamma globulin incorporated into poly ( $D$, L-lactide-co-glycolide) microparticles following oral intubation in Atlantic salmon, Salmo salar L. Fish Shellfish Immunol 6: 507-520.

30. Sourabhan S, Kaladhar K, Sharma CP (2009) Method to enhance the encapsulation of biologically active molecules in PLGA nanoparticles. Trends Biomat Artificial Organs 22: 211-215.

31. Lavelle EC, Jenkins PG, Harris JE (1997) Oral immunization of rainbow trout with antigen microencapsulated in poly (L-lactide-co-glycolide) microparticles. Vaccine 15: 1070-1076.

32. Behera T, Nanda PK, Mohanty C, Mohapatra D, Swaina P, et al. (2010) Parenteral immunization of fish, Labeo rohita with Poly D, L-lactide-co-glycolic acid (PLGA) encapsulated antigen microparticles promotes innate and adaptive immune responses. Fish Shellfish Immunol 28: 320-325.

33. Scheule RK (2000) The role of CpG motifs in immunostimulation and gene therapy. Adv Drug Deliv Rev 44: 119-134.

34. Krieg,AM (2000) The role of CpG motifs in innate immunity. Cur Opin Immuno 12: $35-43$

35. Krieg AM (2002) From A to Z on CpG. Trends Immunol 23: 64-65.

36. Tassakka AC, Sakai M (2005) Current research on the stimulatory effects of CpG oligodeoxynucleotides in fish. Aquaculture 46: 25-36.

37. Diwan M, Tafaghodi M, Samuel J (2002) Enhancement of immune responses by co-delivery of a $\mathrm{CpG}$ oligodeoxynucleotide and tetanus toxoid in biodegradable nanospheres. J Control Rel 85: 247-262.

38. Harikrishnan R, Balasundaram C, Heo MS (2009) Effect of chemotherapy, vaccination and immunomodulation in goldfish, Carassius auratus against Aeromonas hydrophila. Dis Aquat Org 88: 45-54.

39. Amend DF (1981) Potency testing of fish vaccines. Dev Biol Standard 49: 447-454

40. Quade MJ, Roth JA (1997) A rapid, direct assay to measure degranulation of bovine neutrophil primary granules. Vet Immunol Immunopathol 58: 239-248.

41. Anderson DP, Siwicki AK (1994) Duration of protection against Aeromonas salmonicida in brook trout immunostimulated with glucan or chitosan by injection and immersion. Prog Fish Cultu 56: 258-261.

42. Blazer VS, Wolke RE (1984) The effects of a-tocopherol on the immune response and non-specific resistance factors of rainbow trout (Salmo gairdner Richardson). Aquaculture 37: 1-9.

43. Newman KD, Elamanchili P, Kwon GS, Samuel J (2002) Uptake of poly( L-lactic-co-glycolic acid) microspheres by antigenpresenting cells in vivo. J Biomed Mater Res 60: 480-486.

44. Venkataprasad N, Coombes AGA, Singh M, Rohde M, Wilkinson K, et al (1999) Induction of cellular immunity to a mycobacterial antigen adsorbed on lamellar particles of lactide polymers. Vaccine 17: 1814-1819.

45. Gupta RK, Siber GR (1995) Adjuvants for human vaccines-current status, problems and future prospects. Vaccine 13: 1263-1276.

46. Krieg AM (1999) Mechanisms and applications of immune stimulatory CPG oligodeoxynucleotides. Biochim Biophys Acta BBA Gene Struct Expr 1489: 107-116.

47. Morris W, Steinhoff MC, Russell PK (1994) Potential of polymer microencapsulation technology for vaccine innovation. Vaccine 12: 5-11.

48. O'Hagan DT, Singh M (2003) Microparticles as vaccine adjuvants and delivery systems. Expert Rev Vaccines 2: 269-283. 
Citation: Yogeshwari G, Jagruthi C, Arockiaraj J, Harikrishnan R (2015) Poly D, L-lactide-co-glycolic Acid (PLGA)-encapsulated CpG-oligonucleotide (ODN) on Immune Response in Cyprinus carpio against Aeromonas hydrophila. J Aquac Res Development 6: 327. doi:10.4172/21559546.1000327

49. McKeever U, Barman S, Hao T, Chambers P, Song S, et al. (2002) Protective immune responses elicited in mice by immunization with formulations of poly (lactide-co-glycolide) microparticles. Vaccine 20: 1524-1531.

50. Mueller M, Schlosser E, Gander B, Groettrup M (2011) Tumor eradication by immunotherapy with biodegradable PLGA microspheres-an alternative to incomplete Freund's adjuvant. Int J Cancer 129: 407-416.

51. Stine MM (2007) Expression of pro-inflammatory cytokines in Atlantic salmon (Salmo salar) after intraperitoneal injection of PLGA [poly (D-L-lactidecoglycolic) acid] particles.

52. Gupta RK, Singh M, O'Hagan DT (1998) Poly(lactide-co-glycolide) microparticles for the development of single-dose controlled-release vaccines. Adv Drug Del Rev 32: 225-246.

53. Meng Z, Shao J, Xiang L (2003) CpG oligodeoxynucleotides activate grass carp (Ctenopharyngodon idellus) macrophages. Dev Comp Immunol 27: 313-321.

54. Sun H, Pollock KG, Brewer JM (2003) Analysis of the role of vaccine adjuvants in modulating dendritic cell activation and antigen presentation in vitro. Vaccine 21: $849-855$

55. Whitmore MM, Li S, Falo Jr L, Huang L (2001) Systemic administration of LPD prepared with CpG oligonucleotides inhibits the growth of established pulmonary metastases by stimulating innate and acquired antitumor immune responses. Cancer Immunol Immunotherapy 50: 503-514.

56. Klimuk SK, Najar HM, Semple SC, Aslanian S, Dutz JP (2004) Epicutaneous application of $\mathrm{CpG}$ oligodeoxynucleotides with peptide or protein antigen promotes the generation of CTL. J Investig Dermatol 122: 1042-1049.

57. Lee EH, Kim KH (2009) CpG-ODN increases resistance of olive flounder (Paralichthys olivaceus) against Philasterides dicentrarchi (Ciliophora: Scuticociliatia) infection. Fish Shellfish Immunol 26: 29-32.

58. Tassakka ACMAR, Sakai M (2004) Expression of immune-related genes in the common carp (Cyprinus carpio L.) after stimulation by CpG oligodeoxynucleotides. Aquaculture 242: 1-12.
59. Ertl HC, Varga I, Xiang ZQ, Kaiser K, Stephens L, et al. (1996) Poly (D L lactide- coglycolide) microspheres as carriers for peptide vaccine. Vaccine 14 879-885.

60. Uchida T, Goto S, Foster T (1994) Particle size studies for subcutaneous delivery of poly (lactide-co-glycolide) microspheres containing ovalbumin as vaccine formulation. J Pharm Pharmacol 47: 556-560.

61. Carrington AC, Collet B, Holland JW, Secombes CS (2004) CpG oligodeoxynucleotides stimulate immune cell proliferation but not specific antibody production in rainbow trout (Oncorhynchus mykiss). Vet Immunol Immunopathol 101: 211-222.

62. O'Donnell GB, Reilly P, Davidson GA, Ellis AE (1996) The uptake of human gamma globulin incorporated into poly ( $D, L$-lactide-co-glycolide) microparticles following oral intubation in Atlantic salmon, Salmo salar L. Fish Shellfish Immunol 6: 507-520.

63. O'Hagan DT, Jeffery H, Davis SS (1993) Long-term antibody responses in mice following subcutaneous immunization with ovalbumin entrapped in biodegradable microparticles. Vaccine 11: 965-969.

64. Tian Y, Yu J (2011) Poly(lactic-co-glycolic acid) nanoparticles as candidate DNA vaccine carrier for oral immunization of Japanese flounder (Paralichthys olivaceus) against lymphocystis disease virus. Fish Shellfish Immunol 30: 109-117.

65. San Roman B, Irache JM, Gomez S, Tsapis N, Gamazo C, et al. (2008) Coencapsulation of an antigen and CpG oligonucleotides into PLGA microparticles by TROMS technology. Eur J Pharma Biopharmaceutics 70: 98-108.

66. Pridgeon JW, Klesius PH, Mu X, Yancey RJ, Kievit MS, et al. (2012) Efficacy of QCDCR formulated CpG ODN 2007 in Nile tilapia against Streptococcus iniae and identification of upregulated genes. Vet Immunol Immunopathol 145: 179-190.

67. Jørgensen JB, Johansen LH, Steiro K, Johansen A (2003) CpG DNA induces protective antiviral immune responses in Atlantic salmon (Salmo salar L.). J Virol 77: 11471-1149. 